\title{
Asian Sand Dust Up-Regulates MUC4 Expression in Human Upper Airway Epithelial Cells
}

\author{
Chang-Hwi Park ${ }^{1}$, Yoo Sun Song ${ }^{1}$, Chang Hoon Bae ${ }^{1}$, Yoon Seok Choi ${ }^{1}$, \\ Si-Youn Song ${ }^{1}$, Kyeong-Cheol Shin ${ }^{2,3}$, Hyun Jung Jin ${ }^{2,3}$, and Yong-Dae Kim ${ }^{1,3}$ \\ ${ }^{I}$ Departments of Otorhinolaryngology-Head and Neck Surgery, ${ }^{2}$ Internal Medicine, College of Medicine, Yeungnam University, Daegu; \\ and ${ }^{3}$ Regional Center for Respiratory Diseases, Yeungnam University Medical Center, Daegu, Korea
}

\section{사람 상부 호흡기 상피세포에서 황사에 의한 MUC4 점소의 과발현}

박창휘 ${ }^{1} \cdot$ 송유선 ${ }^{1} \cdot$ 배창훈 $^{1} \cdot$ 최윤석 ${ }^{1} \cdot$ 송시연 ${ }^{1} \cdot$ 신경철 $^{2,3} \cdot$ 진현정 ${ }^{2,3} \cdot$ 김용대 $^{1,3}$

영남대학교 의과대학 이비인후-두경부외과학교실, ${ }^{1}$ 내과학교실, ${ }^{2}$ 영남대학교병원 권역 호흡기 전문질환센터 ${ }^{3}$

\author{
Received December 7, 2016 \\ Revised March 21, 2017 \\ Accepted March 22, 2017 \\ Address for correspondence \\ Yong-Dae Kim, MD, PhD \\ Department of Otorhinolaryngology- \\ Head and Neck Surgery, \\ College of Medicine, \\ Yeungnam University, \\ 170 Hyeonchung-ro, Nam-gu, \\ Daegu 42415, Korea \\ Tel $+82-53-620-3781$ \\ Fax $+82-53-628-7884$ \\ E-mail ydkim@med.yu.ac.kr
}

Background and Objectives Asian sand dust (ASD) is a meteorological phenomenon that occurs in spring time in Korea. ASD is composed of various organic and inorganic materials, which induce airway inflammation. MUC4 is an important membrane-bound mucin gene in the human airway, and its expression is increased in pathologic proliferative lesions such as nasal polyps. However, the effect of ASD on MUC4 in human airway epithelial cells is unclear. Therefore, this study aimed to investigate the effect and signaling pathway of ASD on MUC4 expressions in human airway epithelial cells.

Meterials and Method The effect and signaling pathway of ASD on MUC4 expressions were investigated in NCI-H292 cells and in the primary cultures of human nasal epithelial cells using reverse transcription-polymerase chain reaction, real-time polymerase chain reaction, enzyme immunoassay, and immunoblot analysis with several specific inhibitors and small interfering ribonucleic acid (siRNA).

Results ASD induced MUC4 expression and the activated the phosphorylation of extracellular signal-regulated kinase 1/2 (ERK1/2) and p38 mitogen-activated protein kinase (MAPK). An ERK1/2 MAPK inhibitor and a p38 MAPK inhibitor inhibited the ASD-induced MUC4 expression. In addition, the knockdowns of ERK1, ERK2 and p38 MAPK by the respective siRNA blocked the ASD-induced MUC4 mRNA expression. ASD induced toll-like receptor 4 (TLR4) mRNA expression. The knockdown of TLR4 by TLR4 siRNA blocked the phosphorylation of ERK1/2 and p38 MAPK, and the ASD-induced MUC4 mRNA expression.

Conclusion These results show that ASD induces MUC4 expressions via TLR4-dependent ERK1/2 and p38 MAPK signaling pathway in human airway epithelial cells. Korean J Otorhinolaryngol-Head Neck Surg 2017;60(5):222-31

Key Words Airway epithelial cells · Asian sand dust - Mitogen-activated protein kinase · MUC4 $\cdot$ Toll-like receptor 4.

\section{서 론}

점액은 호흡기 상피세포의 표면을 덮고 있는 물질로 습도

This is an Open Access article distributed under the terms of the Creative Commons Attribution Non-Commercial License (http://creativecommons.org/licenses/by-nc/4.0) which permits unrestricted non-commercial use, distribution, and reproduction in any medium, provided the original work is properly cited.
조절 및 윤활 작용과 함께 외부로부터 유입되는 병원체(pathogen)와 각종 화학물질에 대해 물리적 방어벽 역할을 한다. ${ }^{1)}$ 점액 내에 다양한 형태로 존재하는 점소(mucin)는 점액의 성 상을 결정하는 중요한 당단백물질로 점액유전자에 의해 발 현이 조절된다. ${ }^{2}$ 호흡기 점막에는 5 가지 종류의 주요 점소가 두 층으로 나뉘어져 존재하며, 바깥층에는 분비형 점소인 
$\mathrm{MUC5AC}$ 와 MUC5B가, 안층에는 막결합형 점소인 $\mathrm{MUC1}$, $\mathrm{MUC4}, \mathrm{MUC16}$ 이 호흡기 상피의 첨단과 섬모에 부착되어 존재한다. ${ }^{3)} 5$ 가지 주요 점소들은 다양한 자극에 의해 서로 다른 분비양상을 나타내며, 이는 다양한 호흡기 질환의 병태 생리에 밀접한 관련이 있는 것으로 알려져 있다. ${ }^{3,4}$ 그러나, 개 별적인 점소의 생리적인 기능은 충분히 알려져 있지 않아 추 가적인 연구가 필요한 실정이다.

황사(Asian sand dust)는 주로 봄철 아시아 대륙의 건조지대 에서 불려 올라간 다량의 휽먼지가 장거리 이동하여 하늘을 떠 다니며 서서히 하강하는 현상이다. 황사는 이산화규소 $\left(\mathrm{SiO}_{2}\right)$, 산화알루미늄 $\left(\mathrm{Al}_{2} \mathrm{O}_{3}\right)$, 산화철 $\left(\mathrm{Fe}_{2} \mathrm{O}_{3}\right)$, 산화칼슘 $(\mathrm{CaO})$, 산화칼 륨 $\left(\mathrm{K}_{2} \mathrm{O}\right)$ 등 약 13 종의 금속 및 비금속성 산화물과 미량의 구 리 $(\mathrm{Cu})$, 크롬 $(\mathrm{Cr})$, 납 $(\mathrm{Pb})$, 카드뮴 $(\mathrm{Cd})$, 니켈 $(\mathrm{Ni})$ 등 40 종 이상의 미세금속입자로 이루어져 있으며, 대기 중에 존재하는 내독소 (endotoxin)와 같은 다양한 생물에서 기원한 미세 입자들과 함께 흡입된다.) 복합물 형태의 황사는 최근 연구에서 다양한 기전을 통해 호흡기 염증반응을 유발하는 것으로 보고되고 있으며, ${ }^{6-9)}$ 특히 점액분비와 관련된 연구에서는 interleukin-8 과 granulocyte-macrophage colony stimulating factor와 같 은 염증성 사이토카인(cytokine)이 점액유전자 과발현에 영향 을 주는 것으로 알려져 있으며, 특히 최근 연구에서 황사가 주요 분비형 호흡기 점소인 MUC5B와 MUC8의 과분비를 유 발함이 밝혀졌다. 하지만 사람 호흡기 상피세포에서 황사가 점액유전자 발현에 미치는 영향과 기전에 관한 연구는 매우 적으며, 특히 막결합형 점소의 발현에 미치는 영향에 관련된 연구는 전무한 실정이다.

따라서 본 연구에서는 사람호흡기 상피세포에서 황사가 대 표적인 막결합형 점소인 MUC4와 MUC16 발현에 미치는 영향 과 신호전달 경로를 알아보고자 연구를 시행하였다.

\section{재료 및 방법}

\section{재 료}

실험에서 사용된 황사는 대구가톨릭대학교 의과대학 이비 인후과교실에서 제공받았다. 황사 샘플의 채취 방법을 간략 하게 설명하면, 황사는 황사현상이 발생하는 시기에 인천에서 대량 흡입 공기 포집기인 HV-500F(Sibata, Simata, Japan)를 이용하여 수집하였고, 포집기의 여과지를 phosphate buffered saline(PBS) $10 \mathrm{~mL}$ 에 휘저어 황사 분진을 얻었으며, 얻어진 샘플을 $10 \mu \mathrm{M}$ 구멍 크기의 필터를 사용하여 지름 $10 \mu \mathrm{M}$ 이 하의 크기를 가지는 황사 입자를 얻었다. 이렇게 얻어진 황사는 추가적으로 $121^{\circ} \mathrm{C}$ 에서 15 분 동안 가압증기멸균(autoclave)을 하여 멸균된 상태로 만들고 $-20^{\circ} \mathrm{C}$ 에서 냉동 보관하였다가 실
험에 사용하였다. ${ }^{6}$ Fetal bovine serum(FBS)은 HyClone Laboratories Inc.(Logan, UT, USA)에서 구입하였다. Enhanced chemiluminescence kits는 Perkin Elmer Lift Sciences(Boston, MA, USA)에서 구입하였으며, MUC4의 일차 항체는 Neomarker(Zymed, San Francisco, CA, USA)에서 구 입하였고, anti-rabbit or anti-mouse horseradish peroxidase (HRP)-conjugated 이차항체는 Santa Cruz Biotechnology (Santa Cruz, CA, USA)에서 구입하였다.

Extracellular signal-regulated kinase(ERK)1/2 mitogenactivated protein kinase(MAPK), phospho-ERK1/2 MAPK, p38 MAPK 및 phospho-p38 MAPK는 cell signaling technology(Danvers, MA, USA)에서 구입하였으며, U0126(ERK1/ $2 \mathrm{MAPK}$ 선택적 억제제)은 Calbiochem(San Diego, CA, USA) 에서, SB203580(p38 MAPK 선택적 억제제)은 BIOMOL(Plymouth Meeting, PA, USA)에서 구입하였다. Toll-like receptor (TLR) 4 small interfering ribonucleic acid(siRNA)와 ERK1 MAPK siRNA, ERK2 MAPK siRNA, p38 MAPK siRNA, 대조군 siRNA, RPMI 1640 배지, OPTI-MEN I reduced Serum Medium, Lipofectamine 2000은 Invitrogen Corporation(Carlsbad, CA, USA)에서 구입하였고, Human Keratinocyte Growth Supplement(HKGS, 5/500 mL of medium) 가 첨가된 EpiLife Medium은 Cascade Biologics(Portland, $\mathrm{OR}, \mathrm{USA}$ )에서 구입하였다.

\section{세포 배양 및 처치}

사람 폐의 점액상피양 암 세포주(human pulmonary mucoepidermoid carcinoma cell line)인 NCI-H292 세포(American Type Culture Collection, Manassas, VA, USA)를 6-well plate에 $1 \times 10^{6}$ cells/well의 농도로 접종한 후, $2 \mathrm{mM} \mathrm{L-glu-}$ tamine, $100 \mathrm{U} / \mathrm{mL}$ penicillin, $100 \mu \mathrm{g} / \mathrm{mL}$ streptomycin과 $10 \% \mathrm{FBS}$ 가 포함된 RPMI 1640 배지를 이용하여 $95 \%$ 의 산 소와 $5 \%$ 의 이산화탄소가 혼합된 배양기에서 $37^{\circ} \mathrm{C}$ 의 온도로 배양하였다. 70 80\% 정도의 융합기가 되면 세포를 $0.5 \%$ fetal calf serum이 포함된 RPMI 1640 배지로 교체한 후 24시간 동안 배양하고, 다시 FBS가 포함되지 않은 RPMI 1640 배지 로 세척한 후 실험에 사용하였다.

황사의 효과를 알아보기 위해서 NCI-H292 세포에 $10 \mu \mathrm{g} /$ $\mathrm{mL}$ 와 $20 \mu \mathrm{g} / \mathrm{mL}, 40 \mu \mathrm{g} / \mathrm{mL}, 80 \mu \mathrm{g} / \mathrm{mL}$ 농도의 황사를 각각 투여 후 배양하였다. 그리고 U0126과 SB203580에 의한 황 사의 효과를 알아보기 위해 NCI-H292 세포에 $10 \mu \mathrm{g} / \mathrm{mL}$ 와 $20 \mu \mathrm{g} / \mathrm{mL}, 40 \mu \mathrm{g} / \mathrm{mL}, 80 \mu \mathrm{g} / \mathrm{mL}$ 농도의 황사를 전 처치하 기 1 시간 전에 $2 \mu \mathrm{M}$ 의 U0126, $20 \mu \mathrm{M}$ 의 SB203580을 각각 투여하여 배양하였다. 대조군은 동일한 시간 동안 배지에서 
$\mathrm{NCI}-\mathrm{H} 292$ 세포를 단독 배양하였다.

사람의 호흡기 상피세포를 얻기 위해 알레르기에 대한 기저 질환과 가족력이 없고, 피부단자실험(skin prick test)과 multiple simultaneous allergen test에서 음성반응이 나온 10명을 대상으로 하여 융비술 시행 중에 하비갑개 조직을 얻었다. 일 차배양을 하기 위해 하비갑개 점막조직을 PBS로 세척한 후, 90 분 동안 하비갑개 점막조직이 침수될 정도로 dispase(Boehringer Mannheim Biochemica, Mannheim, Germany)에 침전 시켰다. 이후 15 번 수술용 칼로 하비갑개 점막조직을 깨끗하 게 긁어내어 $1 \% \mathrm{PBS}$ 에 담은 후, 200 mesh에 걸러 내고 튜브에 담아 $3000 \mathrm{rpm}$ 에서 5분간 원심 분리하였다. 상층부의 $\mathrm{PBS}$ 를 제거하고 HKGS가 첨가된 EpiLife Medium $6 \mathrm{~mL}$ 를 넣은 후 24-well plate에 $1 \mathrm{~mL}$ 씩 접종하였다. 현미경으로 세포의 양을 확인한 후 2일마다 HKGS를 첨가한 EpiLife Medium 으로 배지를 교체하면서 세포가 70 80\% 정도로 증식되면 실험에 사용하였다. 일차 배양한 하비갑개 점막조직에서 황 사의 효과를 알아보기 위해서 황사 $40 \mu \mathrm{g} / \mathrm{mL}$ 를 전 처치한 후 1 시간 뒤에 각각 $2 \mu \mathrm{M}$ 의 U0126, $20 \mu \mathrm{M}$ 의 SB203580을 투여 하여 배양하였다. 대조군은 동일한 시간 동안 배지에서 호흡 기 상피세포와 NCI-H292 세포를 각각 단독으로 배양하였 다. 실험에서 사용한 NCI-H292 세포와 일차 배양된 하비갑 개 점막 상피세포에 대한 황사의 세포독성 유무는 MTT 분석 (Sigma-Aldrich, St. Louis, MO, USA)과 현미경을 이용한 세 포 형태 변화 유무를 확인하여 검증하였다.

본 연구는 본원 임상시험심사위원회(Institutional Review Board)의 승인을 받아 시행하였다.

\section{Reverse transcription polymerase chain reaction (RT-PCR) 분석}

PTC-200(MF Reseach Inc., Watertown, MA, USA) polymerase chain reaction(PCR) machine과 Gene Amp RNA PCR core kit(Applied Biosystems, Foster City, CA, USA)를 사용하여 제조사의 방법대로 시행하였다. $\mathrm{PCR}$ 에 사용된 oligonucleotide primer는 밝혀진 염기서열에 의해 제작되었 으며, 각 반응의 내부 양성 대조군(internal positive control) 은 glyceraldehyde-3-phosphate dehydrogenase(GAPDH) 를 사용하였다. 실험에 사용된 primer의 염기배열은 MUC4 의 경우 sense는 5'-TTC TAA GAA CCA CCA GAC TCA GAG C-3', antisense는 5'-GAG ACA CAC CTG CAG AGA ATG AGC-3'이다. MUC16의 경우 sense는 5'-GGC TCT ACC TTA ACG GTT ACA ATG AA-3, antisense는 5'-GGT ACC CCA TGG CTG TTG TG-3'이다. GAPDH의 경우 sense는 5'CCT CCA AGG AGT AAG ACC CC-3', antisense는 5'-AGG GGT CTA CAT GGC AAC TG-3'이었 다. 실험에 사용되어 증폭된 mRNA 산물의 크기는 MUC4 는 $467 \mathrm{bp}, \mathrm{MUC16}$ 은 $114 \mathrm{bp}, \mathrm{GAPDH}$ 는 $145 \mathrm{bp}$ 였다. MUC4, MUC16의 reverse transcription polymerase chain reaction (RT-PCR)의 조건과 과정은 이미 보고된 연구들의 방식대로 시행하였다. ${ }^{10)}$ 증폭된 중합효소연쇄반응의 산물은 SYBR green이 함유된 $1 \%$ agarose gel을 통한 전기영동을 이용하여 분리 관찰하였다. 확인된 띠(band)의 세기는 Scion Image software(Scion Corporation, Frederick, MD, USA)를 이용하여 반정량적으로 분석하였고, 대조군의 density를 100으로 하였 을 때 실험군의 density 값을 비율로 나타내어 relative density 로 나타내었다.

\section{Real-time PCR 분석}

합성된 $\mathrm{cDNA} 1 \mu \mathrm{L}$ 를 대상으로 LC Fast Start DNA Master SYBR Green kit(Roche Applied Science, Mannheim, Germany)를 사용하여 real-time $\mathrm{PCR}$ 을 이용한 점액유전자 발현 반응을 시행하였다. Real-time PCR은 최종량이 $10 \mu \mathrm{L}$ 가 되 게 $2.5 \mathrm{mM}$ 의 $\mathrm{MgCl}$ 와 최종 농도가 $0.5 \mu \mathrm{M}$ 이 되게 primer 를 투여하였으며, $25 \mathrm{ng}$ 의 RNA $1 \mu \mathrm{L}$ 를 이용하여 실험을 수 행하였다. 정량적인 PCR은 Light-Cycler(Roche Applied Science, Mannheim, Germany)를 사용하여 $95^{\circ} \mathrm{C}$ 에서 10 초간 변성(denaturation) 과정을 거치고 $60^{\circ} \mathrm{C}$ 에서 5 초간 결합(annealing) 반응을 시킨 후, $72^{\circ} \mathrm{C}$ 에서 10 초간 연장(extension) 반 응하였고, 이러한 과정을 45 회 반복하였다. 증폭의 정확도는 변형곡선(melting curve; Roche Applied Science, Mannheim, Germany)을 사용하여 평가하였다.

\section{면역분석법(Immunoassay)}

MUC4 당단백의 함량을 측정하기 위해서 enzyme-linked immunosorbent assay(ELISA)법을 이용하였다. 시료를 처 리한 배양된 세포에서 lysis buffer[50 mM tris· $\mathrm{Cl}(\mathrm{pH}$ 7.5), $1 \mathrm{mM}$ ethylene glycol tetraacetic acid, $1 \%$ triton X-100, and $1 \mathrm{mM}$ phenylmethylsulfonyl fluoride]로 단백을 추출하여 정 량하였다. 추출한 단백 $100 \mu \mathrm{g}$ 을 96-well plate에 담고 $40^{\circ} \mathrm{C}$ 에서 건조될 때까지 방치한 후 plate를 PBS로 3회 세척하였 다. 비특이적 결합을 방지하기 위해 $2 \%$ bovine serum albumin 으로 실온에서 1 시간 동안 차단한 후 $\mathrm{PBS}$ 로 3 회 세척한 다음 $0.05 \%$ tween 20을 함유한 PBS에 1:200으로 희석된 MUC4 일차항체로 반응시켰다. 다시 $\mathrm{PBS}$ 로 3회 세척한 후 $\mathrm{HRP}-$ conjugated 이차항체를 0.05\% tween 20을 함유한 PBS에 1:5000으로 희석하여 각 well에 첨가하였고, 1 시간 후에 각 well을 PBS로 3회 세척하였다. 3, 3, 5, 5'-tetramethylbenzi- 
dine 용액으로 발색한 후, $2 \mathrm{~N}-\mathrm{H}_{2} \mathrm{SO}_{4}$ 를 이용하여 중단시켰다. ELISA reader(EL800 ${ }^{\circledR}$; BIO-TEK Instruments, Winooski, $\mathrm{VT}, \mathrm{USA}$ )로 $450 \mathrm{~nm}$ 에서 흡광도를 측정한 후 표준곡선을 이용하여 단백의 양을 정량하였다.

\section{Westen blot analysis of p38 and ERK1/2 MAPK phophorylation}

NCI-H292 세포를 6-well plate에 담고 농도에 따라 황사 를 처리하여 접종 후 배양하였다. 이후 trypsin에 각 세포들을 노출시킨 후 lysis buffer를 거쳐 $4{ }^{\circ} \mathrm{C}$ 에서 $700 \times \mathrm{g}$ 으로 원심 분 리시켜 각각의 pellet을 만들었다. 각각의 pellet을 lysis buffer에서 부유한 후 원심분리를 시행하여 정제된 상충액을 whole-cell lysate로 보관하였다. 이러한 방법으로 분리된 50 $\mu \mathrm{g}$ 의 단백을 $10 \%$ reducing sodium dodecyl sulfatepolyacrylamide gel을 이용한 전기영동을 실시하였다. 전기 영동된 $\times$ 단백질을 nitrocellulose membrane으로 옮겨 tris-buffer saline과 tween-20 buffer[20 mM/L Tris- $\mathrm{HCl}(\mathrm{pH}$ 7.6), 135 $\mathrm{mM} / \mathrm{L} \mathrm{NaCl}, 1 \%$ tween-20]와 5\% nonfat dry milk로 처리하 여 항체와의 비특이적 결합을 억제시킨 후 ERK1/2 MAPK 와 p38 MAPK 일차항체로 각각 4시간 반응시켰다. 이후 trisbuffered saline와 tween-20 buffer로 세척하였으며 antimouse HRP-conjugated ERK1/2 MAPK와 p38 MAPK 이 차항체로 각각 1 시간 반응한 다음 세척하여 enhanced chemiluminescence reagent kit를 이용하여 현상하고 10초간 X-ray film에 감광하여 각각의 띠(band)를 확인하였다. 감광 된 띠의 세기는 Scion Image software(Scoin Corporation, Frederick, MD, USA)를 이용하여 반정량적으로 분석하여 상대적 인 density로 나타내었다.

\section{siRNA 형질 전환}

siRNA 형질 전환 실험 사용 순서 및 조건은 ERK1, ERK2 및 p38 MAPK의 siRNA에 대해 게시된 제조사의 방법대로 시 행하였다(Invitrogen Corporation). 간략히 설명하자면 NCI$\mathrm{H} 292$ 세포를 6-well plate에 $1 \times 10^{5}$ cells/well의 농도로 접종 후, RPMI 1640 배지를 이용하여 항생제 없이 하룻밤 동안 배 양하였다. 다음 날 80 90\% 정도의 융합기가 되어 PBS로 세척 한 후, OPTI-MEN I Reduced Serum Medium을 세포에 첨 가하였다. ERK1 MAPK siRNA와 핵산 전송 물질인 Lipofectamine 2000을 ERK1 MAPK siRNA-Lipofectamine 복 합체를 만들기 위해 20분간 OPTI-MEN I Reduced Serum Medium에서 배양 후, ERK1 MAPK siRNA-Lipofectamine 복합체를 함유한 배지를 ERK1 MAPK siRNA $20 \mathrm{nM}$ 농도 로 각각의 well에 첨가 후 $\mathrm{CO}_{2}$ 배양기에서 $37^{\circ} \mathrm{C}$ 로 24 시간 배
양하였다. ERK1 MAPK siRNA-Lipofectamine 복합체 배 지를 형질 전환 활성의 손실 없이 4시간 후 RPMI I640 배지 로 대체한 후 ERK1 MAPK siRNA를 이용하여 24시간 동안 형질 전환을 거친 세포를 $10 \mathrm{ng} / \mathrm{mL}$ 농도의 황사에 노출시키 고, RT-PCR을 이용하여 MUC4 mRNA의 발현량을 측정하 였다. NCI-H292 세포에서 ERK1 MAPK siRNA의 형질 전환 은 90\% 이상으로 측정되었고, TLR4 siRNA와 ERK2 MAPK siRNA, p38 MAPK siRNA, 대조군 siRNA의 형질 전환도 위 와 동일한 과정으로 수행하였다.

\section{통 계}

모든 실험은 3 차례 이상의 반복 실험을 통해 얻은 결과값 을 이용하여 분석하였으며, 통계 처리는 Windows용 SPSS version 10.0(SPSS Inc., Chicago, IL, USA)을 사용하였다. 모든 실험은 $p$ 값이 0.05 미만인 경우를 유의한 것으로 정하여 Student's t-test와 Mann-Whitney U test를 이용하여 분석하 였다.

\section{결 과}

\section{$\mathrm{NCI}-\mathrm{H} 292$ 세포에서 황사가 MUC4와 MUC16 발현에 미치는 영향}

황사가 미치는 주요 호흡기 막결합점소인 MUC4와 MUC16 발현을 알기 위해서 NCI-H292 세포에 각각 다른 농도의 황사 를 투여하여 4시간 동안 배양하였다. RT-PCR 분석 결과, 황사 가 모든 용량에서 MUC4 mRNA 발현을 의미 있게 증가하였 으나, MUC16 mRNA 발현은 대조군과 차이가 없었다(Fig. $1 \mathrm{~A})$. 황사의 용량에 따른 MUC4 mRNA 발현과 당단백 생성 을 알아보고자 NCI-H292 세포에 황사를 투여하고 각각 4시 간과 8시간 동안 배양한 후, 시행한 real time PCR과 ELISA의 분석 결과에서 MUC4 mRNA 발현과 당단백 생성은 모든 용 량에서 증가하였으나, 용량의존성은 없었다(Fig. 1B and C).

황사와 배양 시간에 따른 MUC4 mRNA 발현을 알아보 고자 황사 $40 \mu \mathrm{g}$ 을 NCI-H292 세포에 투여하고 각각 1시간, 2시간, 4시간, 8시간, 24시간을 배양한 후 real time PCR로 MUC4 mRNA 발현을 분석한 결과 배양 4시간 후 MUC4 mRNA 발현이 가장 증가되었으나, 시간 의존성은 관찰되지 않았다(Fig. 1D).

\section{$\mathrm{NCI}-\mathrm{H} 292$ 세포에서 황사가 ERK1/2 MAPK와 p38 MAPK를 통한 MUC4 발현에 미치는 영향}

황사에 의해 유도된 MUC4 발현에서 신호전달 경로를 알 아보기 위하여 NCI-H292 세포에서 ERK1/2 MAPK와 p38 
MAPK 신호전달 경로를 분석하였다. 황사 $40 \mu \mathrm{g}$ 을 투여한 후 시간에 따른 ERK1/2 MAPK와 p38 MAPK의 인산화를 Western blot으로 분석한 결과에서 ERK1/2 MAPK와 p38 $\mathrm{MAPK}$ 가 시간이 경과함에 따라 인산화가 의미 있게 증가하 였다(Fig. 2A).

$\mathrm{ERK} 1 / 2 \mathrm{MAPK}$ 와 $\mathrm{p} 38 \mathrm{MAPK}$ 의 인산화가 황사에 의해 유 도된 MUC4 발현을 증가시키는 신호전달 경로를 확인하기 위해서 NCI-H292 세포에 ERK1/2 MAPK의 억제제인 U0126 $(2 \mu \mathrm{M})$ 과 p38의 억제제인 SB203580 $(20 \mu \mathrm{M})$ 으로 전 처치 후 황사 $40 \mu \mathrm{g}$ 을 투여하고 각각 4시간과 8시간 동안 배양하였다. RT-PCR과 ELISA로 분석한 결과에서 황사에 따른 MUC4 $\mathrm{mRNA}$ 발현과 당단백 생성이 대조군과 비교하였을 때 의미 있게 감소하였다(Fig. 2B and C).

또한 $\mathrm{ERK} 1 / 2 \mathrm{MAPK}$ 와 $\mathrm{p} 38 \mathrm{MAPK}$ 의 신호전달 경로를 검 증하기 위하여 NCI-H292 세포를 ERK1 MAPK siRNA와
ERK2 MAPK siRNA, p38 MAPK siRNA로 각각 표적 유전 자를 knockdown시킨 후 Western blot으로 분석하였으며 충 분한 형질 전환이 일어났음을 확인하였고(Fig. 2D), 각각의 표적유전자 형질 전환을 시행한 후 황사 $40 \mu \mathrm{g}$ 을 투여하였으 며, 4시간 동안 배양 후 MUC4 mRNA의 발현 정도를 RT$\mathrm{PCR}$ 로 측정한 결과 $\mathrm{MUC4} \mathrm{mRNA}$ 의 발현이 대조군과 비교 하였을 때 모두 의미 있게 감소함을 확인하였다(Fig. 2E).

\section{$\mathrm{NCI}-\mathrm{H} 292$ 세포에서 황사가 TLR4를 통한 MUC4 발현에}

\section{미치는 영향}

황사에 의해 유도된 MUC4 발현에 대한 TLR의 역할을 확 인하기 위해 TLR2 mRNA와 TLR4 mRNA의 발현을 RT$\mathrm{PCR}$ 을 통해 분석하였다. 황사가 TLR4 mRNA의 발현을 증 가시켰고, 이는 용량의존성을 보였다. 그러나 TLR2 mRNA 발현은 대조군과 비교하였을 때 차이가 없었다(Fig. 3A).

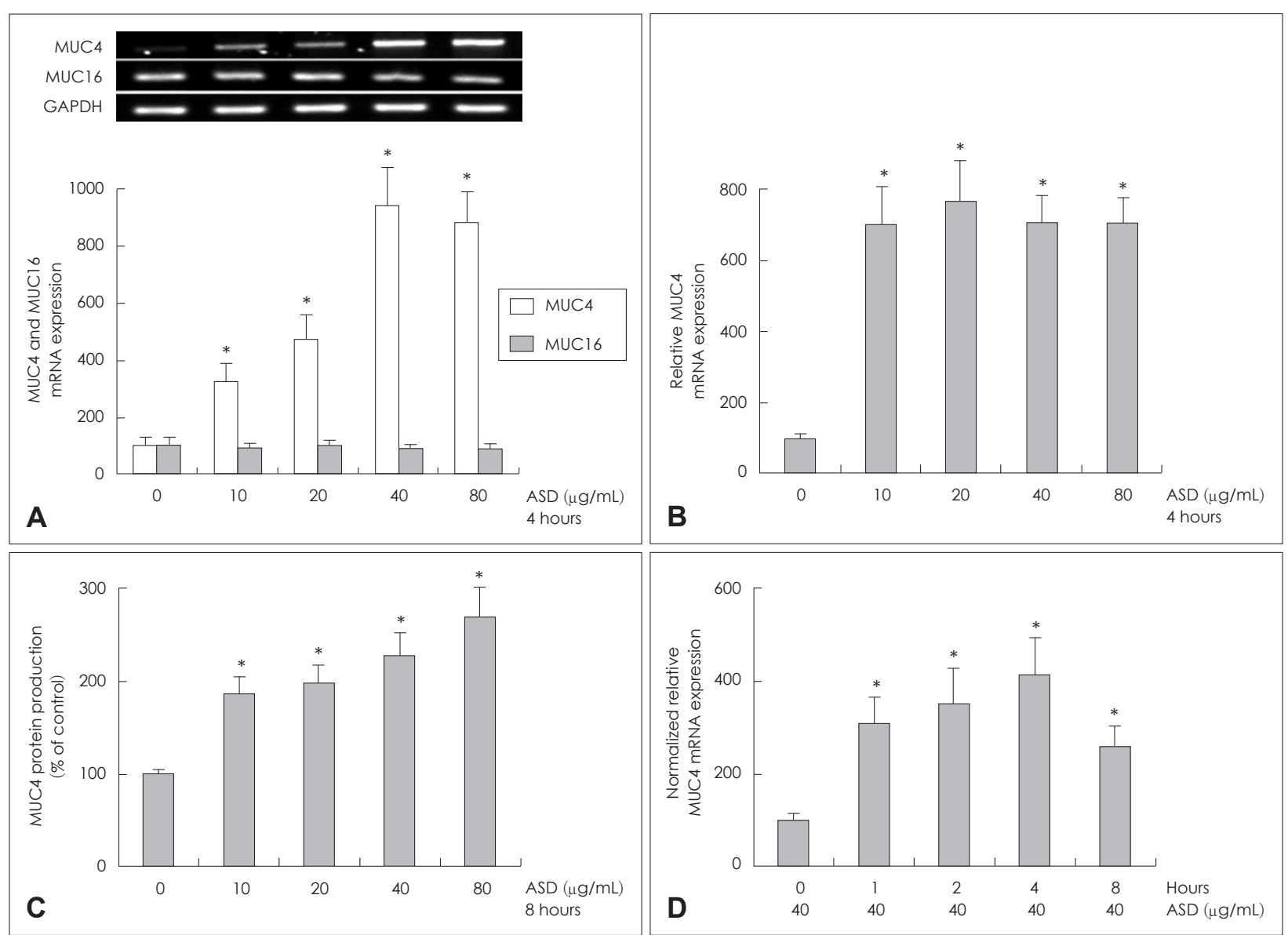

Fig. 1. Effects of ASD on MUC4 and MUC16 expression in NCl-H292 cells. Results of RT-PCR showed that ASD significantly induced MUC4 mRNA expression. However, ASD did not induce MUC16 mRNA expression (A). Results of real-time PCR and ELISA showed that MUC4 mRNA expression and protein production were significantly increased at all concentration of ASD (B and C). Results of realtime PCR showed that MUC4 mRNA expression was significantly increased at all times, and peaked at 4 hours after exposure to ASD $(40 \mu \mathrm{g} / \mathrm{mL})(\mathrm{D})$. Images are representative of three separate experiments performed in triplicate $(n=3)$. Bars indicate the average \pm S.D. of three independent experiments performed in triplicate. ${ }^{*} p<0.05$ vs. baseline. ASD: Asian sand dust, ELISA: enzyme-linked immunosorbent assay, GAPDH: glyceraldehyde-3-phosphate dehydrogenase, RT-PCR: reverse transcription polymerase chain reaction, PCR: polymerase chain reaction. 

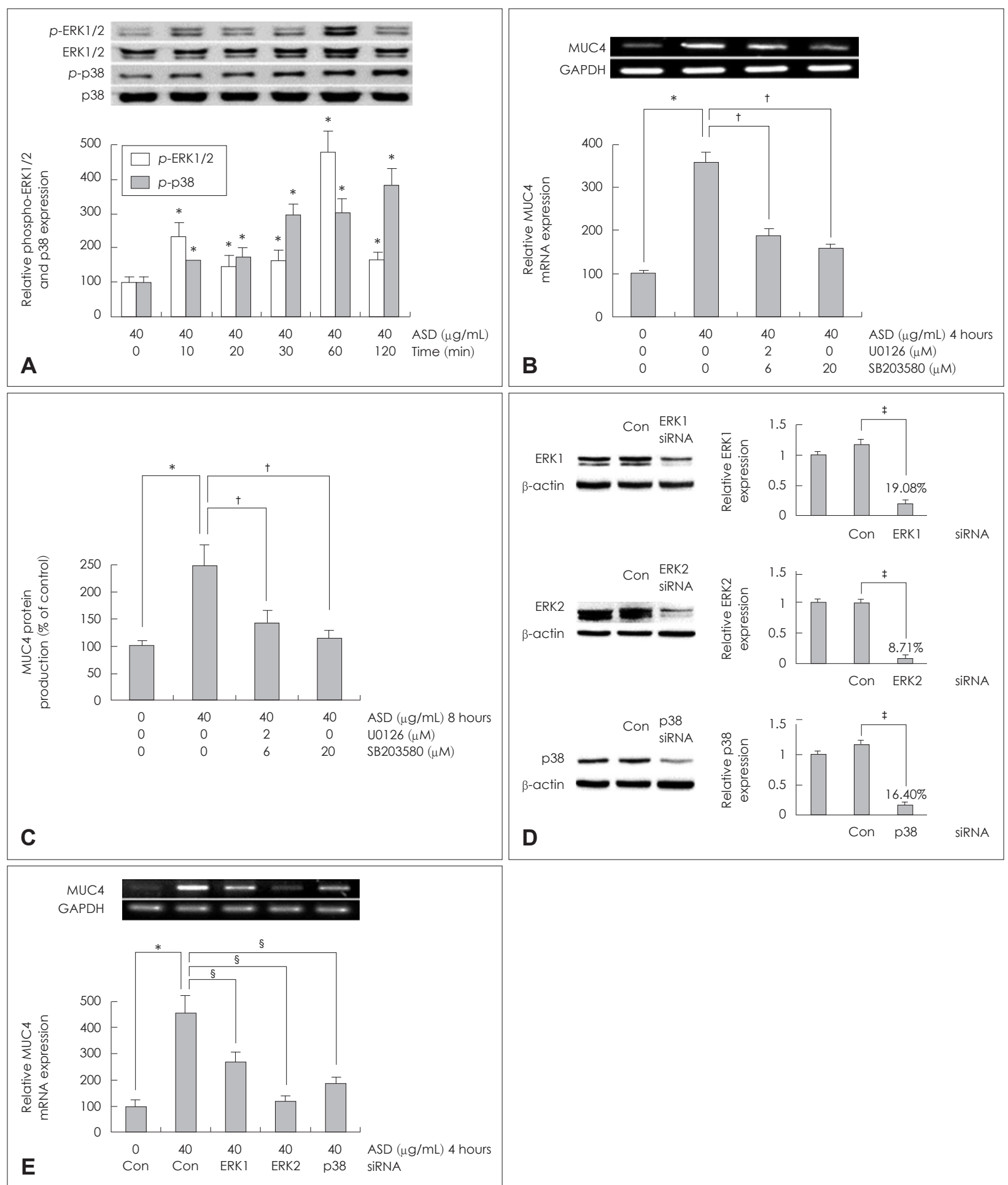

Fig. 2. Effects of ASD on phosphorylation of ERK1/2 and p38 MAPK in NCl-H292 cells. Results of Western blot showed that ASD significantly activated phosphorylation of ERK1/2 and p38 MAPK (A). Results of real-PCR and ELISA showed that U0126 (ERK1/2 MAPK inhibitor) and SB203580 (p38 MAPK inhibitor) significantly inhibited ASD-induced MUC4 mRNA expression and protein production (B and C). Western blot analysis was applied to detect the transfection efficiency (D). Results of RT-PCR showed that knockdown of ERK1, ERK2 and p38 MAPK by siRNA significantly blocked ASD-induced MUC4 mRNA expression (E). Images are representative of three separate experiments performed in triplicate. Bars indicate the average \pm S.D. of three independent experiments performed in triplicate $(\mathrm{n}=3)$. ${ }^{*} p<0.05$ vs. baseline, ${ }^{\dagger} p<0.05$ vs. ASD $(40 \mu \mathrm{g} / \mathrm{mL})$ only, ${ }^{\ddagger} p<0.05$ vs. control siRNA only, ${ }^{\circledR} p<0.05 \mathrm{vs}$. ASD $(40 \mu \mathrm{g} / \mathrm{mL})$ and control siRNA. ASD: Asian sand dust, Con: control siRNA, ERK: extracellular signal-regulated kinase, MAPK: mitogen-activated protein kinase, ELISA: enzyme-linked immunosorbent assay, GAPDH: glyceraldehyde-3-phosphate dehydrogenase, p38: p38 MAPK, RTPCR: reverse transcription polymerase chain reaction, siRNA: small interfering ribonucleic acid, PCR: polymerase chain reaction. 
황사에 의해 유도된 MUC4 발현에서 TLR4와 ERK1/2 MAPK, p38 MAPK의 신호전달 경로를 확인하기 위하여 TLR4 siRNA를 이용하여 knockdown시킨 후 Western blot으로 분 석하였으며 충분한 형질 전환이 일어났음을 확인하였고(Fig. $3 \mathrm{~B})$, 황사 $40 \mu \mathrm{g}$ 을 투여하였으며 1시간 동안 배양한 후 시행한 Western blot 검사 결과 ERK1/2 MAPK와 p38 MAPK의 인산화가 대조군과 비교하였을 때 의미 있게 감소하였고(Fig $3 \mathrm{C})$, 4시간 동안 배양한 후 MUC4 발현정도를 RT-PCR로 분석한 결과 MUC4 mRNA 발현이 대조군과 비교하였을 때 의미 있게 감소함을 확인하였다(Fig. 3D).

\section{하비갑개 점막 상피세포에서 황사가 MUC4 발현에}

\section{미치는 영향}

일차 배양된 하비갑개 점막 상피세포에서 황사의 용량에 따 른 TLR4 mRNA와 MUC4 mRNA 발현에 미치는 영향에 대 해 알아보고자 하비갑개 점막 상피세포에 다양한 용량의 황 사 $(0,10,20,40,80 \mu \mathrm{g})$ 를 처리하였으며, 4시간 동안 배양한 후 시행한 RT-PCR 검사에서 TLR4 mRNA와 MUC4 mRNA 의 발현이 모든 용량에서 의미 있게 증가함을 확인할 수 있었 다(Fig. 4A). 또한 MUC4 당단백 생성 정도를 확인하기 위해 시행한 ELISA 검사에서도 의미 있는 당단백 생성 증가를 확 인할 수 있었다(Fig. 4B). ERK1/2 MAPK의 억제제인 U0126 $(2 \mu \mathrm{M})$ 과 p38의 억제제인 SB203580 $(20 \mu \mathrm{M})$ 으로 전 처치 후
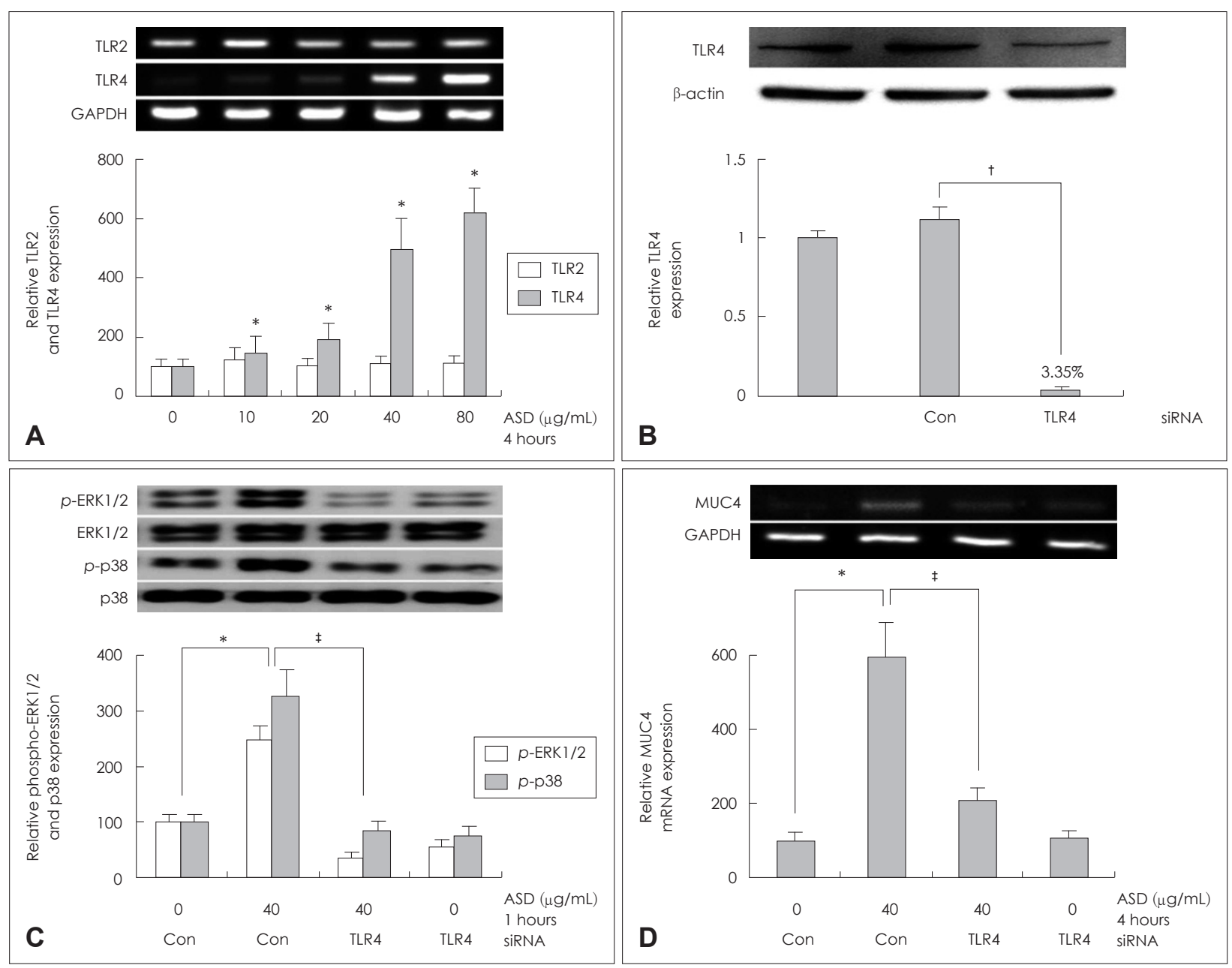

Fig. 3. Roles of TLR in ASD-induced MUC4 expression in NCl-H292 cells. Results of RT-PCR showed that ASD significantly increased TLR4 mRNA expression in dose dependent-manner. However, TLR2 mRNA expression was not increased (A). Western blot analysis was applied to detect the transfection efficiency (B). Results of RT-PCR showed that knockdown of TLR4 by siRNA significantly blocked ASD-induced MUC4 mRNA expression (C). Results of Western blot showed that knockdown of TLR4 by siRNA significantly blocked ASD-induced phosphorylation of ERK1/2 and p38 MAPK (D). Images are representative of three separate experiments performed in triplicate $(n=3)$. Bars indicate the average \pm S.D. of three independent experiments performed in triplicate. ${ }^{*} p<0.05$ vs. baseline, ${ }^{\dagger} p<0.05$ vs. control siRNA only, $\neq_{p}<0.05$ vs. ASD $(40 \mu \mathrm{g} / \mathrm{mL})$ and control siRNA. ASD: Asian sand dust, Con: control siRNA, GAPDH: glyceraldehyde-3-phosphate dehydrogenase, RT-PCR: reverse transcription polymerase chain reaction, siRNA: small interfering ribonucleic acid, TLR: toll-like receptor, MAPK: mitogen-activated protein kinase, ERK: extracellular signal-regulated kinase. 


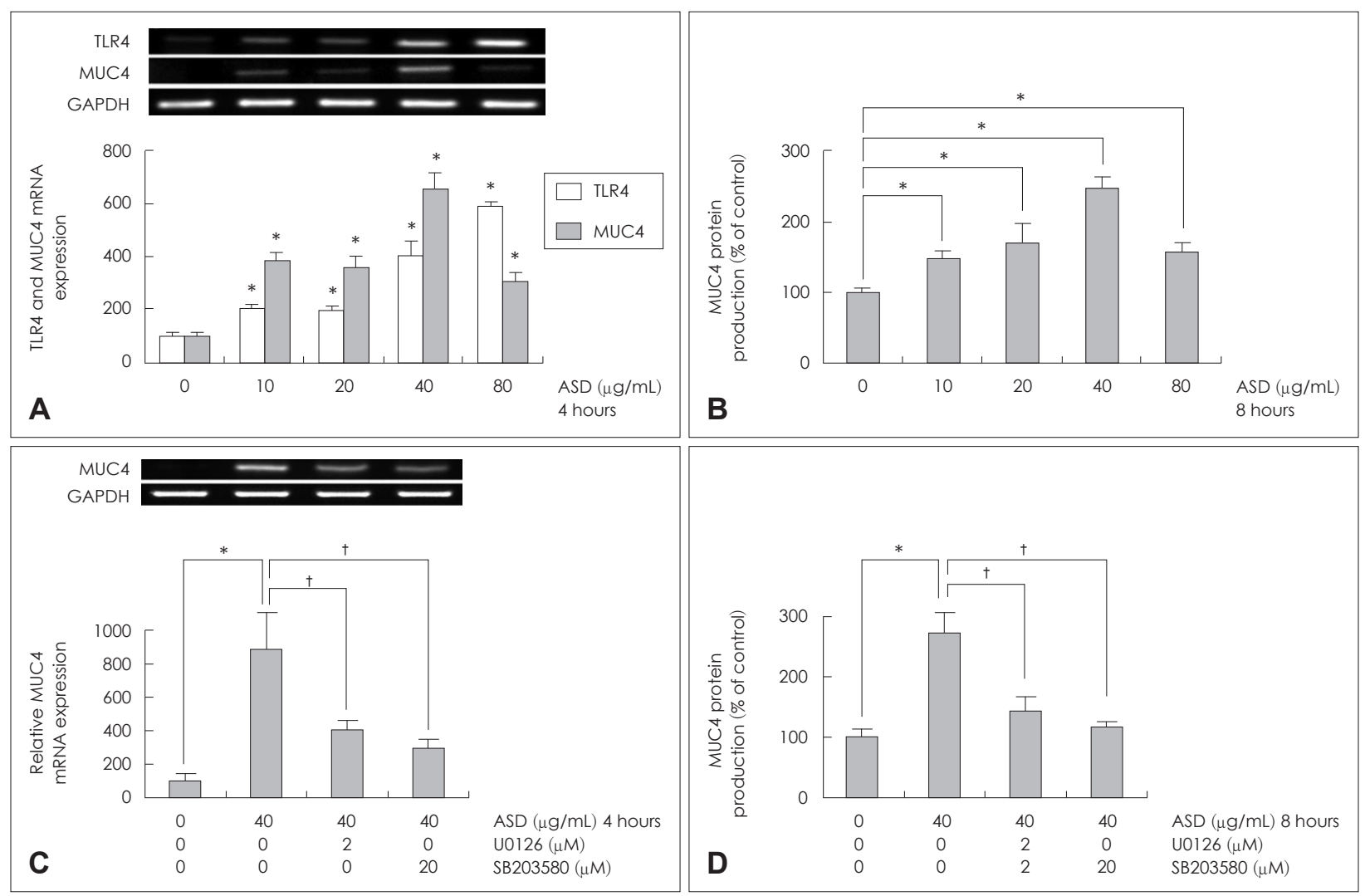

Fig. 4. Effects of ASD on TLR4 and MUC4 expression in human nasal epithelial cells. Results of RT-PCR showed that ASD significantly induced TLR4 and MUC4 mRNA expression (A). Results of ELISA showed that MUC4 protein production were significantly increased at all concentration of ASD (B). Results of RT-PCR and ELISA showed that U0126 (ERK1/2 MAPK inhibitor) and SB203580 (p38 MAPK inhibitor) significantly attenuated ASD-induced MUC4 mRNA expression and protein production (C and D). Images are representative of three separate experiments performed in triplicate $(n=3)$. Bars indicate the average \pm S.D. of three independent experiments performed in triplicate. ${ }^{*} p<0.05$ vs. baseline, ${ }^{\dagger} p<0.05$ vs. ASD $(40 \mu \mathrm{g} / \mathrm{mL})$ only. ASD: Asian sand dust, ELISA: enzyme-linked immunosorbent assay, GAPDH: glyceraldehyde-3-phosphate dehydrogenase, RT-PCR: reverse transcription polymerase chain reaction, TLR: toll-like receptor, ERK: extracellular signal-regulated kinase, MAPK: mitogen-activated protein kinase.

황사 $40 \mu \mathrm{g}$ 를 투여하였을 때는 MUC4 mRNA 발현과 당단 백 생성이 의미 있게 감소하였다(Fig. 4 C and D).

\section{고 찰}

황사는 매년 봄철이면 국내를 포함한 동아시아 지역에서 주기적으로 발생하는 기상현상이다. 황사 현상에서 상대적 으로 크기가 큰 입자들은 주변부 및 발원지에 머물게 되고, 국내에 유입되는 황사 입자의 크기는 대부분 $10 \mu \mathrm{m}$ 이하의 미 세먼지(particulate matter 10)이다. 미세먼지는 흡입 시 하부기관 지 및 폐의 가스-교환부분까지 침착하여 다양한 기전을 통해 호흡기 손상을 유발하는 것으로 알려져 있다.) 특히 최근 연구 에서 황사가 사람 호흡기 상피세포에서 MUC5B와 MUC8 점 액유전자를 과발현시키고," 사람 비용 상피세포에서도 MUC4와 MUC5AC, MUC5B, MUC8의 점액유전자 과발현을 유발한 다고 알려져 있다. ${ }^{8)}$ 그러나, 황사가 호흡기 방어기전의 중요한 점소인 MUC4와 MUC16과 같은 막결합형 점소에 미치는 영
향에 대해서는 연구된 바가 없다. 이에 본 연구에서는 사람의 호흡기 상피세포에서 황사가 주요 막결합형 점소인 MUC4와 MUC16의 발현에 미치는 영향과 관련 기전에 대해 중점을 두 고 연구를 진행하였으며, 본 연구의 결과를 통해 황사가 MUC4 의 과발현을 유발함을 확인할 수 있었다.

호흡기에서 정상적으로 존재하는 MUC4는 MUC1, MUC16 과 함께 호흡기 점액층의 내층을 구성하는 주요 점소로 외부 물질과 손상으로부터 호흡기 점막를 보호하는 기능을 하는 중요한 막결합형 당단백질로 알려져 있다. ${ }^{3)}$ 또한 MUC4는 상 피세포 재상(epithelial cell renewal), 세포 분화(differenciation), 세포 신호전달(cell signaling), 세포 부착(cell adhesion), 암의 발생(cancer development) 등에 관여하는 것으로 알려져 있다. 특히 호흡기 질환에서는 섬암종(adenocarcinoma)에서 높은 발현을 보이며, 섬암종의 감별진단과 예후 평가에 유용 한 바이오마커로 사용되고 있다. ${ }^{11)}$ 또한, 낭성 섬유증(cystic fibrosis)과 만성폐쇄성폐질환(chronic obstructive pulmonary disease) 등의 만성 염증성 호흡기 질환에서도 정상과 다른 


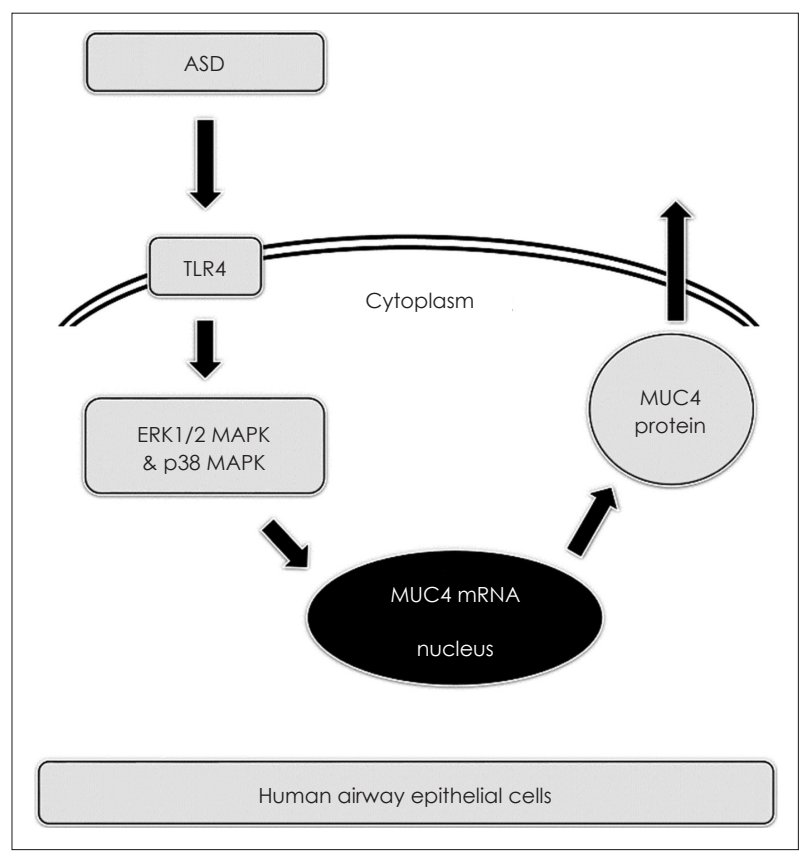

Fig. 5. The schematic signaling pathway of ASD on MUC4 expression in human airway epithelial cells. ASD induces MUC4 expressions via TLR4-dependent ERK1/2 and p38 MAPK signaling pathway. ASD: Asian sand dust, ERK: extracellular signal-regulated kinase, MAPK: mitogen-activated protein kinase, TLR: toll-like receptor.

발현양상을 보이는 것으로 알려져 있다. ${ }^{12,13)}$ 그러나 아직까지 MUC4를 포함한 다양한 막결합형 점소의 생리적 기능과 과 발현이 가지는 병태생리학적 의미에 대해 이해하기 위해서는 추가적인 연구가 필요한 실정이다.

TLR은 호흡기 상피세포에서 외부로부터 유입되는 병원체를 인식하여 선천면역(innate immunity) 반응에 중요한 역할을 담 당하며, 점소 분비 조절에 있어서는 MUC4와 MUC5B, MUC8 발현 증가에 중요한 역할을 한다.7,910,14) 본 연구에서도 사람 호 흡기 상피세포에서 황사에 의한 TLR4 발현 여부를 알아본 결과 황사가 TLR4 발현을 유도한다는 것을 알 수 있었다.

사람의 호흡기 상피세포에서 주요 점액유전자 발현의 신 호전달 경로 중 ERK1/2 MAPK와 p38 MAPK에 대한 연구 들을 살펴보면, spleen tyrosine kinase와 delphinidin이 ERK1/2 MAPK 또는 p38 MAPK 신호전달 경로를 통해 MUC5AC 발현과 MUC5B 발현, MUC8 발현을 유도하였으 며, ${ }^{14,15)} \beta$-glucan과 phorbol 12-myristate 13-acetate는 p38 MAPK 신호전달 경로를 통해 MUC4 발현을 유도하였고, ${ }^{10,16}$ 특히 황사가 ERK2 MAPK와 p38 MAPK 신호전달 경로를 통해 MUC5B와 MUC8 발현을 유도하였다. ${ }^{7)}$ 이에 본 연구에 서도 황사가 MUC4 발현 유도에 있어 ERK1/2 MAPK와 p38 MAPK 신호전달 경로가 중요한 역할을 할 것으로 생각되어 확인해 본 결과 황사가 ERK1/2 MAPK와 $\mathrm{p} 38 \mathrm{MAPK}$ 인산화
를 의미 있게 증가시켰고, ERK1/2 MAPK와 p38 MAPK 인 산화를 억제하였을 경우 황사에 의한 MUC4 발현이 감소됨 을 확인할 수 있었다. 이를 통해 황사가 ERK1/2 MAPK와 p38 MAPK 신호전달 경로를 통해 MUC4 발현을 증가시키 는 것을 알 수 있었다. 또한 황사에 의한 MUC4 발현의 증가 에 있어서 TLR4, ERK1/2 MAPK, p38 MAPK의 연관성을 확인해 본 결과 기존의 연구들과 유사하게 TLR4에 매개된 ERK1/2 MAPK와 p38 MAPK 신호전달 체계의 활성화가 연관되어 있음을 확인할 수 있었다(Fig. 5). 그러나 본 연구 의 제한점은 막결합성 점소의 분석에서 $\mathrm{MUC1}$ 의 발현변화 를 확인하지 못하였다는 점, 복합물인 황사의 성분에 대한 개별적 효과에 대한 검증이 부족하다는 점과 세포에만 국한 된 실험 결과이므로 추가적인 동물실험을 통해 연구 결과에 대한 확인이 필요하다는 점을 들 수 있겠다. 이를 해결하기 위해서 추가적인 연구가 뒤따라야 할 것으로 생각된다.

결론적으로 본 연구 결과를 통해 황사가 TLR4에 의존한 ERK1/2 MAPK와 p38 MAPK 신호전달 경로를 통해 MUC4 발현을 증가시키는 것을 알 수 있었고, 이는 황사와 관련된 다 양한 호흡기 질환의 병태생리를 이해하는 데 중요한 기초자 료가 될 것으로 생각된다.

\section{REFERENCES}

1) Ali MS, Pearson JP. Upper airway mucin gene expression: a review. Laryngoscope 2007;117(5):932-8.

2) Williams OW, Sharafkhaneh A, Kim V, Dickey BF, Evans CM. Airway mucus: from production to secretion. Am J Respir Cell Mol Biol 2006;34(5):527-36.

3) Kim KC. Role of epithelial mucins during airway infection. Pulm Pharmacol Ther 2012;25(6):415-9.

4) Martínez-Antón A, Debolós C, Garrido M, Roca-Ferrer J, Barranco $\mathrm{C}$, Alobid I, et al. Mucin genes have different expression patterns in healthy and diseased upper airway mucosa. Clin Exp Allergy 2006;36(4):448-57.

5) Jung JH, Kang IG, Cha HE, Choe SH, Kim ST. Effect of Asian sand dust on mucin production in NCI-H292 cells and allergic murine model. Otolaryngol Head Neck Surg 2012;146(6):887-94.

6) Kim JH, Jeon HK, Kim MK, Kyung SY, An CH, Lee SP, et al. Particulate matter from Asian dust storms induces the expression of proinflammatory cytokine in A549 epithelial cells. Tuberc Respir Dis 2006;60(6):663-72.

7) Choi YS, Bae CH, Song SY, Kim YD. Asian sand dust increases MUC8 and MUC5B expressions via TLR4-dependent ERK2 and p38 MAPK in human airway epithelial cells. Am J Rhinol Allergy 2015;29(3):161-5.

8) Kim ST, Ye MK, Shin SH. Effects of Asian sand dust on mucin gene expression and activation of nasal polyp epithelial cells. Am J Rhinol Allergy 2011;25(5):303-6.

9) Ichinose T, Yoshida S, Hiyoshi K, Sadakane K, Takano H, Nishikawa $\mathrm{M}$, et al. The effects of microbial materials adhered to Asian sand dust on allergic lung inflammation. Arch Environ Contam Toxicol 2008; 55:348-57.

10) Kim YD, Bae CH, Song SY, Choi YS. Effect of $\beta$-glucan on MUC4 and MUC5B expression in human airway epithelial cells. Int Forum Allergy Rhinol 2015;5(8):708-15. 
11) Chaturvedi P, Singh AP, Batra SK. Structure, evolution, and biology of the MUC4 mucin. FASEB J 2008;22(4):966-81.

12) Lamblin G, Degroote S, Perini JM, Delmotte P, Scharfman A, Davril $\mathrm{M}$, et al. Human airway mucin glycosylation: a combinatory of carbohydrate determinants which vary in cystic fibrosis. Glycoconj J 2001;18(9):661-84.

13) Leikauf GD, Borchers MT, Prows DR, Simpson LG. Mucin apoprotein expression in COPD. Chest 2002;121(5 Suppl):166S-82S.

14) Bae CH, Jeon BS, Choi YS, Song SY, Kim YD. Delphinidin inhibits
LPS-Induced MUC8 and MUC5B expression through toll-like receptor 4-mediated ERK1/2 and p38 MAPK in human airway epithelial cells. Clin Exp Otorhinolaryngol 2014;7(3):198-204.

15) Na HG, Bae CH, Choi YS, Song SY, Kim YD. Spleen tyrosine kinase induces MUC5AC expression in human airway epithelial cell. Am J Rhinol Allergy 2016;30(2):89-93.

16) Bae CH, Kim HS, Song SY, Kim YD. Phorbol 12-myristate 13-acetate induces MUC16 expression via $\mathrm{PKC} \delta$ and $\mathrm{p} 38$ in human airway epithelial cells. Clin Exp Otorhinolaryngol 2012;5(3):161-9. 